\title{
The status of Elateridae (Coleoptera) in India
}

\author{
Malsawmdawngzuali Tara \\ Department of Life Sciences, Pachhunga University College, Mizoram University, Aizawl 796001, Mizoram
}

\begin{abstract}
Beetles are a group of insects that form the order Coleoptera, in the superorder Endopterygota. It is estimated that a quarter of all described species in the world belongs to this order. The family Elateridae or click beetles is the ninth-largest family under this order. Wireworms are the larval stage of this family and they play a role in the ecosystem as they are omnivorous and act as pests. There are over 800 species of elaterids recorded from the Indian Subcontinent under eight subfamilies. India is rich in floral and faunal diversity and insect diversity in particular constitute about $6 \%$ of all identified insects in the world with a large number being endemic species. But in contrast to its extreme species richness, there is comparatively very little knowledge about this family of beetles when compared to other families. And as such, there is still a lot of potential to study its ecology and diversity. It is also because of this same reason that review of the status of the elaterid family is being done as a prequel to the actual field study.
\end{abstract}

Received 18 January 2021 Accepted 15 February 2021

*For correspondence: m.tara@pucollege.edu.in

Contact us: sciencevision@outlook.com

Keywords: Click beetles, Coleoptera, Diversity, India, taxonomy.

\section{Introduction}

Beetles belong to the order Coleoptera, the largest order of insects and has an estimated 3,50,000 species that are classified into 4 sub orders and 177 families. ${ }^{1}$ The distinguishing feature of beetles is the modified forewings into hardened protective cover called 'elytra' while the hindwings are entirely membranous and folded and hidden beneath the elytra and they have adapted to almost all types of habitats, from aquatic to soil, trees, foliage, and are present in almost all types of ecosystems with the exclusion of the Polar Regions. They can range in size from $1 \mathrm{~mm}$ to approximately $75 \mathrm{~mm}$ in length. ${ }^{2}$ In India alone, more than 15,500 species of beetles have been recorded. ${ }^{3}$ Under the order Coleoptera, there are around 176 extant families and 32 fossil families. ${ }^{4}$

\section{The family Elateridae}

The family Elateridae Leach, 1815 contains approximately 400 genera with nearly 10,000 identified species worldwide, which makes it the ninth largest family under the order Coleoptera. ${ }^{5} \mathrm{An}$ adult elaterid can be easily identified by the elongated elytra which narrow posteriorly and the posterior corners of the protonum being prolonged pointedly. The presence of a backward pointing spine on its venter, originating between the front pairs of legs and fitting into the grove between the middle pair of legs, allows for it to 'click' when the insect is on its back. The representatives of this family are commonly called "Click beetles" due to this unique jumping and clicking mechanism.

Click beetles can be found in a range of ecosystems, from grasslands to deciduous and evergreen forests and some are even found at an 
altitude of more than $3000 \mathrm{~m} .{ }^{6,7}$ The adult stage of this family comprises of both nocturnal and diurnal species. During the day, they can be found hidden under the bark and in rotting wood, stones and crevices, etc. and can also be occasionally found resting on foliage and flowers. At night they are attracted to yellow, black and white light. In terms of feeding habits, adult beetles may be nectarivorous, pollen feeders or phytophagous. The larvae of these beetles are commonly known as "wire worms" and are mostly mycetophagous, phytophagous, saproxylic, rhizophagous and even predatory in some species. ${ }^{8-12}$ The larvae are found in soil, moss, leaf litter and in rotting wood. Rhizophagous species are major pests of economically important crops like sugarcane, groundnut, potato, maize, and tobacco. ${ }^{13}$

\section{Early Taxonomic Studies}

The first record of Elateridae was given by Linnaeus ${ }^{14}$ in 1758 and all the then known elaterids were put under one genus Elater Linnaeus. The first elaterid species described from India is Calais speciosus Linnaeus, 1767 and was reported as Elater speciosus Linn. ${ }^{15}$ Lanelater fuscipes Fabricius was described by Fabricius in $1775^{16}$ from South India, and the same author also gave description for Elater luridus $^{17}$ and Elater tomentosus ${ }^{18}$ (now both under Lanelater) in 1798 and 1891 respectively.

In 1806 , Herbst ${ }^{19}$ provided a description for the species Elater muticus. In 1840, Lacon mustellinus Fabricius was described by Germer ${ }^{20}$, and $\mathrm{Kollar}^{21}$, in 1844, described a new species Lacon brachychaetus from Kashmir. Candeze, ${ }^{22-31}$ a Belgian entomologist, also contributed a lot towards the study of this family in India and in between 1857 to 1900, recorded over 50 species from different parts of India. Westwood ${ }^{32}$ described two click beetles from North-East India. In 1858, Russian enotomologist Motschulsky ${ }^{33}$ described a new species Trachylacon lobicollis (now under Adelocera) from India. Schwarz in $1902^{34}$ and $1905^{35}$ described Lacon oberndorferi and Pericus oberndorferi, and Lacon niger and Allotypus duchoni from South India with specimens collected from Madras and catalogued and described few species from North-East India. ${ }^{36-38}$ Fowler $^{39}$ in "Fauna of British India" provided brief reports of elaterids without providing keys to the family. Fleutiaux ${ }^{40}$ provided a revised description on a number of elaterid species from Indo-Burma region. One of the series of works by Stibick, ${ }_{1}^{41}$ dedicated to Indian species provided a revision of 12 species under 2 genera from different parts of India.

\section{Recent Taxonomic Studies}

The more recent works on Elateridae in India include the works by Vats ${ }^{42-48}$ and his co-workers, who carried out surveys in the North Indian states including Haryana, Himachal Pradesh, Punjab,
Rajasthan, Uttarakhand and some parts of Jammu \& Kashmir. They reported and described around 168 species of elaterids under 37 genera, and among these, 139 species were reported as new species and among these 57 species belonging to Agrypninae. Garg et al. ${ }^{49-53}$ reported several new species of elaterids and has also added to the elaterid fauna of North India and also worked on revised keys for a number of genus of this family.

Schimmel ${ }^{54}$ during the Czech-Republic expedition to the Western Ghats of Maharashtra in India in 2005, collected 23 species belonging to 11 genera of Elateridae and from this expedition reported several new records for the state as well as one new species Podeonius borowieci. Schimmel and Tarnawski $i^{55-57}$ also contributed extensively to the knowledge of elaterid fauna of the Himalayan region and described six new species from the genus Mulsanteus Gozis from regions of China, Malaysia and India. Three new species of the genus Corymbitodes Buysson, 1904 from Nepal and India ware described by Schimmel and Tarnawski, ${ }^{58}$ with a description of the male of Corymbitodes kambaitiana Fleutiaux, 1942. Patwardhan ${ }^{59-64}$ and co-workers have also contributed to the elaterid knowledge of the Western Ghats with several new records for the state of Maharashtra and provided description for ten species, as well as description of a new genus Punctodensus which is endemic to this region. The most recent in the taxonomic study of the family elaterid came from Patwardhan \& Khot $^{67}$ who, just recently, reported and described a new species Lampropsephus sulcatus Fleutiaux, 1928 from Konkan in Maharashtra.

Chakraborty \& Chakrabarti ${ }^{68-69}$ reported as many as 172 species under 37 genera from West Bengal and listed about 140 species of elaterids from the subfamily Agrypninae from India. Ghosh et al. ${ }^{70}$ reported 4 species of Elateridae from Sunderban Biosphere Reserve, out of which 2 species namely Cardiophorus tibialis Erichson, 1991 and Cardiophorus aequabilis Candeze, 1860 are reported for the first time in the state of West Bengal. From Buxa Tiger Reserve within the same state, Sarkar et al. ${ }^{71}$ reported 12 species of Elateridae.

From among the north-east states, the survey and records of the Zoological Survey of India reported 45 specimens under 16 genera belonging to 9 sub families from Sikkim, ${ }^{72}$ with description of a new species under the genera Meristhus Candeze and Cardiophorus Eschscholtz. From the state of Manipur, 12 species under 7 genera and 6 subfamilies have been recorded. ${ }^{73}$ There has not been any other survey work for Elateridae from the other North-East states, nor is there any IUCN status on any elaterid beetles for India.

\section{Conclusion}

Although being one of the largest families of 
beetles, the elaterids are not studied as extensively as other families and because of this, very little is known about their ecology and life cycle when compared with other families like Scarabaeidae and Cerambycidae. This may be due to its elusive nature or extreme morphological homogeneity. The complete and detailed life cycle is also known only for some economically important species like Cryptalaus spp. or Athous spp. whose status as pests gives them higher focus for research. The present knowledge about the faunal composition of elaterids within the Indian Subcontinent is represented by 835 species and 113 genera coming under 8 subfamilies. ${ }^{74}$ There is still a lot to be learned about this family of elusive beetles, and especially in the northeast states of the Himalayan biodiversity hotspot region, there is believed to be more species which are yet to be discovered upon further investigations and adding to the present knowledge.

\section{Conflict of interest}

The author declared no conflict of interest.

\section{References}

1. Alfred, J.R.B., Das, A.K. \& Sanyal, A.K. (1998), Faunal Diversity of India, ENVIS Centre, Zoological Survey of India, Calcutta, pp. 259-268.

2. Borror, D.J., Delong, D.M. \& Triplehorn, C.A. (1976). An introduction to the study of insects. (4th ed.) Holt and Winston, New York, p. 852.

3. Sengupta, T. \& Pal, T.K. (1998). Faunal diversity in India: Coleoptera. Records of Zoological Survey of India, Kolkata, pp. 132-139.

4. Bouchard, P., Smith, A. B. T., Douglas, H., Gimmel, M. L., Brunke, A. J., \& Kanda, K. (2017). Biodiversity of Coleoptera. In R. Foottit \& P. Adler (Eds.), Insect Biodiversity: Science and Society: Vol. I (Second, Issue July7). John Wiley \& Sons Ltd, pp. $337-41$.

5. Leach, W.E. (1815). Entomology. Edinburgh Encyclopaedia: D. Brewster (Ed.) W. Blackwood, J Waugh, etc., Edinburgh, Vol. IX, pp. 57-172.

6. Kundrata, R. (2012). Taxonomic review of the Himalayan species of Selasia Laporte,1836 (Coleoptera: Elateridae: Agrypninae: Drilini). Annales Zoologici, 62(2), 261-266.

7. Kundrata, R., Musalkova, M., \& Prosvirov, A. S. (2018). Annotated catalogue of the click-beetle tribe Senodoniini (Coleoptera: Elateridae: Dendrometrinae). Zootaxa, 4532(2), 273-287.

8. Arimoto, K. (2016). Taxonomic notes on three species of the genus Agonischius (Coleoptera,
Elateridae, Elaterinae, Elaterini) with a new species from Taiwan. Zootaxa, 4114(2), 149-161.

9. Costa, C., Lawrence, J. F., \& Rosa, S. (2010). Elateridae Leach, 1815. In R. A. Leschen, R. G. Beutel, \& J. F. Lawrence (Eds.), Coleoptera, Beetles, Volume 2: Morphology and Systematics (Elateroidea, Bostrichiformia, Cucujiformia partim). In N.P. Kristensen, R.G. Beutel (Eds.) Handbook of Zoology, Arthropoda: Insecta (pp. 75103). Walter de Gruyter GmbH and Co KG, Berlin/ New York.

10. Costa, C., \& Vanin, S. A. (2010). Coleoptera larval fauna associated with termite nests (Isoptera) with emphasis on the "Bioluminescent Termite Nests" from Central Brazil. Psyche, 1-12.

11. Dollin, P., Majka, C., \& Duinker, P. (2008). Saproxylic beetle (Coleoptera) communities and forest management practices in coniferous stands in southwest Nova Scotia, Canada. ZooKeys, 2, 291 $-336$.

12. Gimmel, M. L., \& Ferro, M. L. (2018). General Overview of Saproxylic Coleoptera. In M. D. Ulyshen (Ed.), Saproxylic Insects: Diversity, Ecology and Conservation. Springer, Heidelberg, pp. 51-128.

13. Stebbing, E. P. (1914). Indian Forest Insects of Economic Importance. Eyre and Spottiswoode, Ltd., London.

14. Linnaeus, C. (1758). Systema Naturae per Regna Tria Naturae, secundum Classes, Ordines, Genera, Species, cum Characteribus, Differentiis, Synonymis, Locis. Tomus (Decima Edi). Holmiae.

15. Linnaeus, C. (1767). Systema naturae per regna tria naturae, secundum classes, ordines, genera, species, cum characteribus, differentiis, synonymis, locis. Editio duodecima, reformata. Tomus I. Pars II. Laurentii Salvii, Holmiae.

16. Fabricius, J. C. (1775). Systema entomologiae, sistens insectorum classes, ordines, genera, species, adiectis synonymis, locis, descriptionibus, observationibus. Flensburgi, Lipsiae. (Kort).

17. Fabricius, J. C. (1781.) Species Insectorum Exhibentes eorum differentias specificas, synonyma auctorum, loca natalia, metamorphosin, adjectis observationibus, descriptionibus, Volume 1. Hamburg: Carol Ernest.

18. Fabricius, J. C. (1798). Supplementum entomologiae systematicae. Hafniae : apud Proft et Storch.

19. Herbst, J. F. W. (1806). Natursystem aller bekannten in und aus handischen Insecten. Kafer, Berlin, 10, viii+ 285 pp. 19 pis

20. Germar, E. F. (1840). Bemerkungen uber Elatetiden. Z. Ent. (Germar) 1: 241-279. 
21. Kollar, V. (1844). Coleoptera. In C. F. Von. Huegel, Kaschmir und das Reich der Siek 4 part 2, 497-564. Stuttgart.

22. Candeze, E. C. A. (1857). Monographie des Elatérides. Tome premier. (Issue 12). Mémoires de la Société Royale des Sciences de Liege.

23. Candeze, E. C. A. (1859). Monographie des Elatérides. Tome deuxiéme. (Issue 14). Mémoires de la Société Royale des Sciences de Liege.

24. Candeze, E. C. A. (1860). Monographie des Elatérides. Tome troisiéme. (Issue 15). Mémoires de la Société Royale des Sciences de Liege.

25. Candeze, E. C. A. (1863). Monographie des Elatérides. Tome quatriéme. (Issue 17). Mémoires de la Société Royale des Sciences de Liege.

26. Candeze, E. C. A. (1865). Elatérides nouveaux. Mémoires del'Académie de Belgique, 17, 1-63.

27. Candeze, E. C. A. (1874). Revision de la Monographie des Elatérides. Fasc. 1. Mémoires de La Société Royale Des Sciences de Liége, 2, 1-218.

28. Candeze, E. C. A. (1878). Elatérides nouveaux. Annales de La Société Entomologique de Belgique, 21, $51-61$.

29. Candeze, E. C. A. (1878). Elatérides nouveaux. Annales de La Société Entomologique de Belgique, 21, $161-172$.

30. Candeze, E. C. A. (1878). Elatérides nouveaux. Annales de La Société Entomologique de Belgique, 21, 189-199.

31. Candeze, E. C. A. (1893). Addition aux Elatérides des Indes Orientales. Annales de La Société Entomologique de Belgique, 37, 168-179.

32. Westwood, J. 0. (1848). The cabinet of Oriental entomology; being a selection of some of the rarer and more beautiful species of insects, natives of India and the adjacent islands, the greater portion of which are now for the first time described and figured. William Smith, London.

33. Motschulsky, V. De. (1858). Insects des Indes Orientales. Etudes entomologigues. Helsingfors. 7, 20 -122 .

34. Schwarz, O. (1902). Neue Elateriden aus dem tropischen Asien, den malayischen Inseln und den Inseln der Sudsee. Deutsche Entomologische Zeitung, pp. 305-350.

35. Schwarz, O. (1905). Neue Elateriden aus der Malayischen zone. Deutsche Entomologische Zeitung, pp. 257-266.

36. Schwarz, O. (1902). Neue Elateriden. Stettiner Entomologische Zeitung, 63, 194-316.
37. Schwarz, O. (1906). Coleoptera. Fam. Elateridae. In P. A. Wytsman (Ed.), Genera Insectorum: Vol. VII (Issue Fascicules 46A, 46B, pp. 1-112, 113-224). P. Wytsman, Bruxelles.

38. Schwarz, O. (1907). Coleoptera. Fam. Elateridae. In P. Wytsman (Ed.), Genera Insectorum: Vol. VII(Issue Fascicules 46C, pp. 225-370). P. Wytsman, Bruxelles.

39. Fowler, W. W.(1912). Coleoptera. General Introduction and Cicindelidae and Paussidae. In A. E. Shipley (Ed.), The Fauna of British India, including Ceylon and Burma. Taylor and Francis (London), Fleet Street, Calcutta.

40. Fleutiaux, E. (1947). Revision des Elaterides (Coléopteres) de 1'Indo-Chine Francaise. Premiere partie. Notes D"Entomologie Chinoise, 11, 233-420.

41. Stibick, J. N. L. (1980). A revision of the Hypnoidinae of the world (Coleoptera: Elateridae). Part IV. The Hypnoidinae of India. Section 12. Eos, 54(1-4), $247-273$.

42. Vats, L. K., \& Chauhan, R. L. (1992). Description of species of Anchastus LeConte from North India (Coleoptera: Elateridae). Journal of Entomological Research, 16(3), 85-188.

43. Vats, L. K., \& Chauhan, R. L. (1992). New species of Ludiinae (Coleoptera: Elateridae). Journal of Entomological Research, 16(3), 189-192.

44. Vats, L. K., \& Chauhan, R. L. (1992). Two new species of Adiaphorus Candeze from North India (Coleoptera: Elateridae). Journal of Entomological Research, 6(3), 177-180.

45. Vats, L. K., \& Chauhan, R. L. (1992). Two new species of Ampedinae (Coleoptera: Elateridae). Journal of Entomological Research, 16(l), 20-23.

46. Vats, L. K., \& Kashyap, S. L. (1992). Forty-eight species of Agrypnos Eschscholtz including forty new additions from North-West India (Coleoptera: Elateridae). Journal of Entomological Research, 16(2), 87-154.

47. Vats, L. K., \& Kashyap, S. L. (1992). Seven new species of Adelocera Latreille from North-West India (Coleoptera: Elateridae). Journal of Entomological Research, 16(l), 1-12.

48. Vats, L. K., \& Kashyap, S. L. (1996). Species of Meristhus Candeze from North India (Coleoptera: Elateridae: Agrypninae). Journal of Entomological Research, 20(1), 67-72.

49. Garg, P., Saini, M. S., \& Vasu, V. (1997). New additions to the Indian fauna of Agrypnus Eschscholtz (Coleoptera: Elateridae: Agrypninae). Journal of Entomological Research, 21, 283-289. 
50. Garg,P., Saini, M.S., \&Vasu, V. (1998). New species of Silesia Candeze(Coleoptera: Elateridae: Adrastinae) from India. Journal of the Bombay Natural History Society, 95, pp. 460-464.

51. Garg, P., \& Vasu, V. (1996). Two new species and a revised key to genus Neodiploconus Hyslop (Coleoptera: Elateridae: Melanotinae) from India. Journal of the Bombay Natural History Society, 93, $260-262$.

52. Garg, P., \& Vasu, V. (1999). New species of Agonischius Candeze (Coleoptera: Elateridae: Ludiinae) from India. Journal of the Bombay Natural History Society, 96, 281-284.

53. Garg, P., Vasu, V., \& Vats, L. K. (1995). A new species of Monadicus Candeze (Coleoptera: Elateridae: Hypnoidinae) together with a key to Indian species. Journal of Entomological Research, 19 (4), 363-365.

54. Schimmel, R. (2007). New records on Elateridae, and description of a new species from Westghats in India (Insecta/ : Coleoptera). Genus (Wroclaw), 18(2), 221-238.

55. Schimmel, R., \& Tarnawski, D. (2010). Monograph of the subtribe Elaterina (Insecta: Coleoptera: Elateridae: Elaterinae). Genus (Wroclaw), 21(3), 325-487.

56. Schimmel, R., \& Tarnawski, D. (2011). New and little known species of the tribe quasimusini schimmel et tarnawski, 2009 (Coleoptera: Elateridae) from palaearctic and oriental regions. Annales Zoologici, 61(3), 453-462.

57. Schimmel, R., \& Tarnawski, D. (2011). Six new species of the genus Mulsanteus Gozis, 1875 from China, India and Malaysia (Insecta: Coleoptera: Elateridae).Genus (Wroclaw), 22(4), 565-577.

58. Schimmel, R., \& Tarnawski, D. (2015). Three new species of the genus Corymbitodes Buysson, 1904 from Nepal and India with a description of the male of Corymbitodes kambaitiana Fleutiaux, 1942 (Coleoptera: Elateridae). Zootaxa, 3925(4), 551-561.

59. Patwardhan, A., \& Athalye, R. P. (2010). New records and two new species of Cardiophorine Elateridae from Maharashtra, India (Insecta: Coleoptera). Genus (Wroclaw), 21(4), 505-511.

60. Patwardhan, A., \& Athalye, R. P. (2010). Two new species of Dicrepidiini from Maharashtra, India with note on structure of hind wing and genitalia of some previously described species (Coleoptera: Elateridae). Genus (Wroclaw), 21(1), 43-52.

61. Patwardhan, A., \& Athalye, R. P. (2012). Plectrosternus Lacordaire, 1857 (Coleoptera: Elateridae); Genus new to northern Western Ghats,
India with a description of one new species. Zootaxa, 3193, 53-61.

62. Patwardhan, A., Platia, G., \& Athalye, R. P. (2008). A New Species of Metriaulacus

63. Schwarz, 1901 From Maharashtra, India. Bionano Frontier, 2(l), 15-17.

64. Patwardhan, A., Schimmel, R., \& Atalye, R. P. (2008). A new species of Xanthopenthes Fleutiaux 1928 from Maharashtra, India (Coleoptera: Elateridae). Genus (Wroclaw), 19(4), 675-678.

65. Patwardhan, A., Schimmel, R., \& Athalye, R. P. (2009). A new genus Punctodensus from North Western Ghat, Maharashtra, India (Coleoptera: Elateridae: Agrypninae: Hemirrhipini). Genus (Wroclaw), 20(1), 53-60.

66. Patwardhan, A., \& Khot, R. (2020). Description of a new species of the genus Lampropsephus Fleutiaux, 1928 (Coleoptera: Elateridae: Elaterinae: Dicrepidiini) from Konkan, Maharashtra, India. Journal of Threatened Taxa, 12(1), 15181-15185.

67. Chakraborty, P., \& Chakrabarti, S. (2000). Agrypninae (Coleoptera: Elateridae) of India: A taxonomic review and checklist. Records of Zoological Survey of India, 98(3), 71-83.

68. Chakraborty, P., \& Chakrabarti, S. (2006). A contribution to the fauna of Click- Beetles (Coleoptera: Elateroidea: Elateridae) of West Bengal. Records of Zoological Survey of India, 254, $1-220$.

69. Ghosh, Paramita \& Chakraborti, Udipta \& Biswas, Olive \& Roy, Sankarsan \& Mitra, Bulganin. (2017). First record of family Elateridae (Coleoptera: Elateridae) from Sundarban biosphere reserve with addition of two species from West Bengal, India. International Journal of Entomology Research. 2, 2455-4758.

70. Sarkar, S., Saha, S., Raychaudhuri, D. (2012). Munis Entomology \& Zoology, 7(2), 1195-1198.

71. Chakraborty, P., \& Chakraborty, S. (2003). Insecta: Coleoptera : Elateridae (Elateroidea). Zoological Survey of India. State Fauna Series 9, Fauna of Sikkim (Part-3), 217-236.

72. Chakraborty, P., \& Chakraborty, S. (2004). Insecta: Coleoptera : Elateridae (Elateroidea). Zoological Survey of India. State Fauna Series 10 : Fauna of Manipur, pp. 353-358.

73. Patwardhan, P., Parekar, H. V., \& Athalye, R.P. (2020). Click Beetles (Coleoptera: Elateridae) of India: An Overview. Phenomenon in Environmental and Nano Science, 25-43. 